
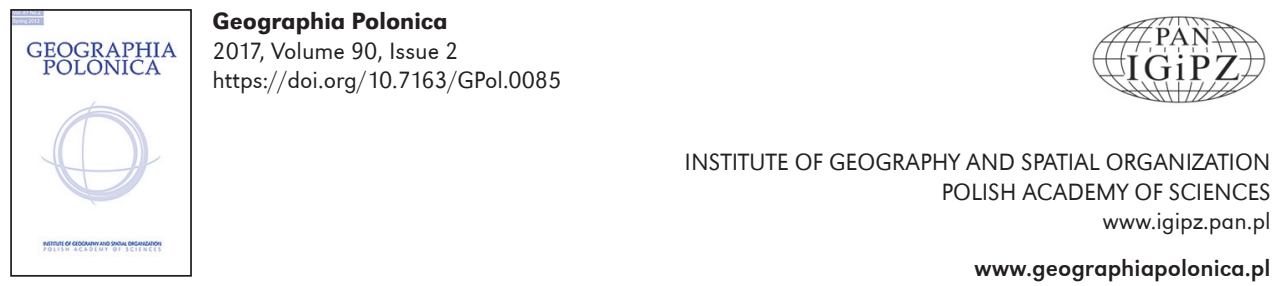

INSTITUTE OF GEOGRAPHY AND SPATIAL ORGANIZATION POLISH ACADEMY OF SCIENCES www.igipz.pan.pl

\title{
DOES SUBURBANISATION CONTRIBUTE TO THE REJUVENATION OF A METROPOLITAN AREA? CHANGES IN THE AGE STRUCTURE OF THE KRAKÓW METROPOLITAN AREA IN POLAND IN THE LIGHT OF RECENT SUBURBANISATION
}

\author{
Sławomir Kurek ${ }^{1}$ • Mirosław Wójtowicz ${ }^{1}$ Jadwiga Gałka ${ }^{2}$ \\ ${ }^{1}$ Institute of Geography \\ Pedagogical University of Kraków \\ Podchorażych 2, 30-084 Kraków: Poland \\ e-mails: sgkurek@up.krakow.pl・mwojt@up.krakow.pl \\ ${ }^{2}$ Institute of Geography and Spatial Management \\ Jagiellonian University \\ Gronostajowa 7, 30-387 Kraków: Poland \\ e-mail: jadwiga.galka@uj.edu.pl
}

\begin{abstract}
The process of residential suburbanisation may cause changes in the age structure of the population as the age composition of in-migrants is younger than long-term residents. However, the demographic change associated with the second demographic transition as well as the co-existence of suburbanisation and reurbanisation of inner city areas may have ambiguous impacts on the age composition. The aim of this paper is to show changes in the age structure of the population in a post-socialist city in the light of suburbanisation using the example of the Kraków Metropolitan Area. In particular, we sought to show whether the intensive development of this process results in the inhibition of population ageing due to the influx of people in suburban areas along with the outward diffusion of the behaviours associated with the second demographic transition.
\end{abstract}

\section{Key words}

suburbanisation • age composition • population ageing • post-socialist city • Kraków • Poland

\section{Introduction}

Suburbanisation is a common feature of large post-socialist cities in Central and Eastern Europe (Ouředníček 2003; Drozg 2004; Reberik 2004; Sedláková 2005; Kåhrik
\& Tammaru 2008). It is a stage of urban development which undoubtedly changes the physiognomy of metropolitan areas both in post-socialist countries, e.g. in the Czech Republic (Ouředniček 2007), in Estonia (Leetmaa 
\& Tammaru 2007), in Poland (Lisowski \& Grochowski 2008) and Slovenia (Mihai et al. 2015) as well as in western European countries and the USA (Cheshire 1995; Chin 2002). The process leads to urban sprawl and the spreading of the city's lifestyles into suburban areas (Pichler-Milanović 2007). Suburbanisation may also influence the change in the demographic composition of a population as a result of mobility between the inner city and the suburbs (Ouředníček \& Temelová 2009).

However, the issue of the impact of suburbanisation on changes in the age composition of a population living in suburban areas has been neglected in Poland and other countries in Central-Eastern Europe. A main shortcoming in the current literature is the focus of many studies on total population change at the macro-scale, while neglecting to recognise changes in the age composition, especially at the micro-level (Kabisch \& Haase 2011; Kabisch et al. 2012). Existing research concentrates more on the rejuvenation of city centres due to gentrification and in some towns due to reurbanisation (Haase et al. 2010; Kabisch et al. 2010; Kroll \& Kabisch 2012). In periurban areas long-standing trends towards greater natural decrease have been reversed by the in-migration and retention of young adults in childbearing age groups. In this ringshaped zone, growth processes generate net in-migration from both the inner and outer sides (migration from outlying rural and urban areas) and population increases within the region itself (Ford 1999).

Apart from the above research, few studies conclude that suburbanisation causes changes in the age structure of a population, even though they occur more slowly than changes associated with the natural movement of the population. The influx of younger age groups to suburban areas will initially slow down the ageing of the population in those areas, but it will also increase this process in urban centres (Kurek 2011a,b; Marcińczak 2012). The slowing down of population ageing may be also an effect of increasing fertility due to the selective suburbanisation of households and women who intend to have a larger family
(Kulu \& Boyle 2009; Vobecka \& Piguet 2012). This generalisation also applies to suburbs with large numbers of foreign immigrants (Bayona-Carrasco \& Gil-Alonso 2012).

An increase in the share of the elderly population in urban centres may, however, slow down over time due to gentrification, but in the nearby suburban areas the process of ageing in-place can be observed (Swiaczny et al. 2008; Kerbler 2015). For example, in the metropolitan areas of Kraków, Poznań and Warsaw, rapid ageing of the population was observed during the 1990s in the central areas of the cities, whereas in the first decade of the twenty-first century the external zones of these metropolitan areas were experiencing more rapid ageing (Kurek 2011b).

The ageing of the population in suburban areas has been the subject of research for some time now due both to the poor adaptation of the transport infrastructure and to the decreasing mobility of people in old age (Rosenbloom 2003; Lord \& Luxembourg 2006; Zeitler et al. 2012). In suburban areas, the residents mostly use their own means of transport and lack sufficient transport accessibility for the elderly in terms of the number of public transport stops, facilities for using public transport and connections inside the suburban area itself.

The aim of this paper is to answer the question whether suburbanisation is leading to a rejuvenation of the population age composition in Kraków Metropolitan Area in Poland. In particular, we address the following research questions:

1. How is the age composition of in-migrants to suburban areas different from in-migrants to the inner city?

2. Which changes were recorded in the age composition of the population living in the Kraków Metropolitan Area and in particular certain rings?

3. Are fertility levels and birth rate changes in the inner city and suburban zone the result of suburbanisation?

To answer these questions we first provide an analysis of the migration flows to and from Kraków as well as its suburban zone. Then 
Does suburbanisation contribute to the rejuvenation of a metropolitan area? Changes in the age...

we investigate the percentage changes in the age composition of the population of the inner city, suburban and commuting zones. Next, we observe trends in recent total fertility rates as well as birth rates in the Kraków Metropolitan Area. Finally, we conclude by addressing how current processes of urban development and population change, including the second demographic transition, affect population age composition in metropolitan areas in Central Eastern Europe.

\section{Methodology and study area}

Our investigation outlined in this article is based on statistical data derived from the Central Statistical Office in Warsaw. We studied data on changes in specific economic age classes (that is, the pre-working population aged under 18, mobile working population aged 18-44, immobile working population of females aged 45-59 females and males aged 44-64 and post-working population aged 60+ for females and 65+ for males) in the Kraków Metropolitan Area (KMA) and its main rings (Fig. 1). An analysis was made of the period 1988-2012, mainly based on the following years: 1988, 1995, 2002 and 2012. In addition, the year 1988 presents the conditions before the beginning of the socio-economic transformation, which had an impact on demographic changes in post-socialist countries (declines in birth rates and increases in international migration). The age composition of in-migrants to Kraków and the suburban zone, as noted above, is our major focus.

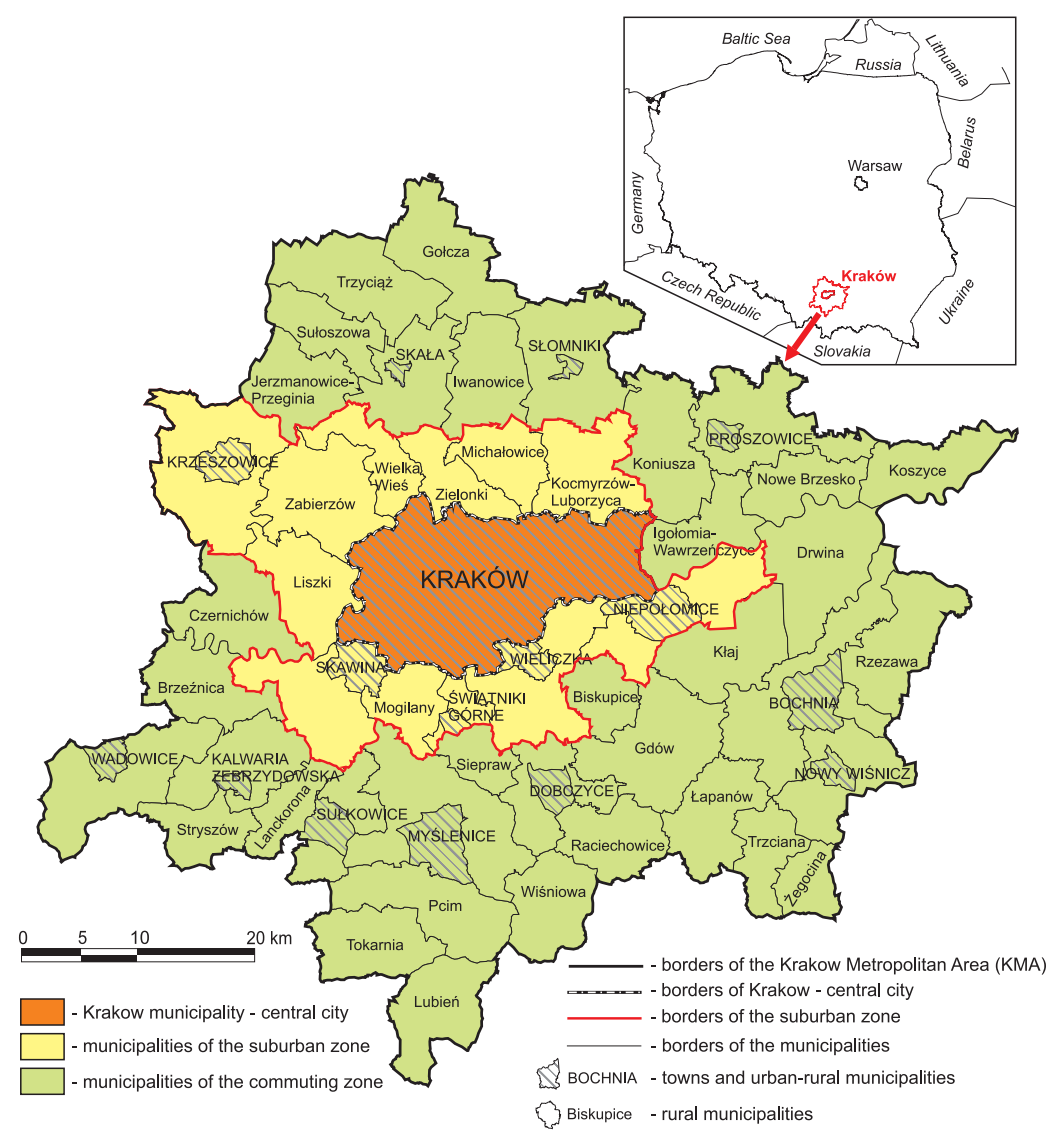

Figure 1. The spatial extent of the Kraków Metropolitan Area (KMA) (PPZWM 2003) 
The Kraków Metropolitan Area (KMA) is a functional region which includes the city along with adjacent counties. The KMA has 65 spatial units, all which were included in this analysis. In 2012, the KMA region had a population of 1.493 million people, of which 758 thousand or 60.8 percent reside in Kraków itself.

\section{Results}

The main demographic factor responsible for the level of suburbanisation in the Kraków Metropolitan Area was the high level of inmigration and an age composition of newcomers that was younger than the resident population. According to official statistical data about 45 thousand people migrated from Kraków to suburban areas and 23 thousand to the commuting zone from 1990-2012. On the other hand, Kraków itself maintained positive values of net migration in this period as it attracted about 57 thousand people from outside of the KMA. More than two-thirds of all in-migration to Kraków from 1990-2012 constituted people of mobile working age, that is, those from 18 to 44 years old, while about 18 per cent accounted for the pre-working age population (aged under 18; Tab. 1). However, when we take into account the total in-migration to the suburban zones of the KMA, we notice that the proportion of migrants aged under 18 was much higher than to Kraków (almost 28 per cent) and the percentages of pre-working and young workers accounted for more than 80 per cent of total in-migrants (Tab. 1). The difference in the share of the working population was in favour of in-migrants to Kraków (almost 10 per cent) which was associated with more employment opportunities for the economically active population. The transfer of industrial activity and services (especially services related to retail and wholesale) known as industrial and service suburbanisation was much slower than residential suburbanisation (Hermelin 2007; Sykora \& Ouředniček 2007; Kurek et al. 2014). More in-migrants to suburban areas were in the older working age cohort than there were in Kraków itself. Mutual flows between Kraków and its suburban zones recorded a high percentage of pre-working population while the in-flow from outside of the metropolitan area to Kraków was characterised by a higher share of younger workers.

When examining changes in the structure by economic age group in Kraków Metropolitan Area (KMA), it is clear that they do not deviate from the general worldwide trends related to the aging of the population. These

Table 1. Migration flows to Kraków and suburban areas: 1990-2012

\begin{tabular}{|l|c|c|c|c|c|}
\hline \multirow{2}{*}{ Flow direction } & Pre-working & $\begin{array}{c}\text { Mobile } \\
\text { working }\end{array}$ & $\begin{array}{r}\text { Immobile } \\
\text { working }\end{array}$ & $\begin{array}{c}\text { Post- } \\
\text { working }\end{array}$ & Total \\
\cline { 2 - 6 } & \multicolumn{5}{|c|}{ number of people } \\
\hline In-migration suburban to Kraków & 4,156 & 9,687 & 1,834 & 1,152 & 16,829 \\
In-migration Kraków to suburban & 12,738 & 21,912 & 7,457 & 2,880 & 44,987 \\
In-migration to Kraków total & 24,885 & 97,574 & 10,492 & 8,280 & 141,231 \\
In-migration to suburban total & 22,668 & 45,919 & 11,087 & 4,947 & 84,621 \\
\hline & \multicolumn{7}{|c|}{ percentages } & & \\
\hline In-migration suburban to Kraków & 24.7 & 57.6 & 10.9 & 6.8 & 100 \\
In-migration Kraków to suburban & 28.3 & 48.7 & 16.6 & 6.4 & 100 \\
In-migration to Kraków total & 17.6 & 69.1 & 7.4 & 5.9 & 100 \\
In-migration to suburban total & 26.8 & 54.3 & 13.1 & 5.8 & 100 \\
\hline
\end{tabular}

Source: Our analysis based on data from the Central Statistical Office, Warsaw (the same applies to Tab. 2). 
Does suburbanisation contribute to the rejuvenation of a metropolitan area? Changes in the age...

Table 2. Absolute and relative changes in the population of the Kraków Metropolitan Area (KMA) and its zones by age group: 1988-2012

\begin{tabular}{|c|c|c|c|c|c|c|c|c|c|c|c|c|}
\hline \multirow{3}{*}{ Age group } & \multicolumn{4}{|c|}{1988} & \multicolumn{4}{|c|}{2012} & \multicolumn{4}{|c|}{ Change 1988-2012 } \\
\hline & Kraków & $\begin{array}{c}\text { Subur- } \\
\text { ban }\end{array}$ & $\begin{array}{l}\text { Com- } \\
\text { muting }\end{array}$ & KMA & Kraków & $\begin{array}{l}\text { Subur- } \\
\text { ban }\end{array}$ & $\begin{array}{l}\text { Com- } \\
\text { muting }\end{array}$ & KMA & Kraków & $\begin{array}{l}\text { Subur- } \\
\text { ban }\end{array}$ & $\begin{array}{l}\text { Com- } \\
\text { muting }\end{array}$ & KMA \\
\hline & \multicolumn{8}{|c|}{ In thousands of people } & \multicolumn{4}{|c|}{$1988=100$} \\
\hline Pre-working & 187.6 & 51.6 & 142.1 & 381.3 & 117.1 & 45.9 & 105.8 & 268.9 & 62.4 & 89.9 & 74.5 & 70.5 \\
\hline Mobile working & 321.2 & 68.3 & 172.7 & 562.2 & 316.2 & 92.8 & 209.0 & 618.0 & 98.5 & 135.8 & 121.0 & 109.9 \\
\hline Immobile working & 142.8 & 30.3 & 76.6 & 249.7 & 169.6 & 51.6 & 114.1 & 335.3 & 118.7 & 170.5 & 149.0 & 134.3 \\
\hline Post-working & 94.0 & 23.5 & 64.7 & 182.2 & 155.3 & 35.0 & 80.5 & 270.8 & 165.2 & 148.8 & 124.5 & 148.6 \\
\hline Total & 745.6 & 173.7 & 456.0 & 1375.4 & 758.3 & 225.3 & 509.4 & 1493.0 & 101.7 & 129.7 & 111.7 & 108.6 \\
\hline
\end{tabular}

show a decrease in the share of people in the pre-working age and an increase in the share of the population in retirement age as a result of fertility decline, increasing life expectancy and migration (Rogers \& Raymer 1999; Walford \& Kurek 2008; Stockdale 2011; Botev 2012; Pavlova \& Silbereisen 2012; Sharma 2012; Song et al. 2012; Rees et al. 2012). In the period 1988-2012, the total population of KMA increased from 1375 to 1493 thousand, however the highest percentage increase was recorded in the suburban zone (by 30 per cent). Despite the increase in total population, there were differences between the population changes in particular age groups (Tab. 2). In all zones of the KMA the number in the preworking population declined, while the number of the immobile and retired population showed a marked increase. The percentage decline of the pre-working population amounted to nearly 10 percentage points, and the increase in the proportion of people of retirement age stood at nearly 5 percentage points. In the period analysed, there was an increase in the share of the working age population, except that this growth was mainly the result of an increase in the proportion of people in the immobile working age (Fig. 2).

Taking account of all zones in the KMA in the period of time analysed, the lowest percentage of people in the pre-working age cohort was found in Kraków (Fig. 3). Furthermore the share of the population in this age group was increasing with increasing distance from the city centre. However in recent years the percentage of this population was almost the same in the suburban zone and in the commuting zone, which recorded the largest decline (10.4 percent).

In contrast to studies done by Ouředniček in Prague (2007), which indicate that the migration to suburban zones has an impact on the rejuvenation of the age structure of the population through a selective influx of population in the reproductive age, in Kraków Metropolitan Area, selective in-migration of young people of child-bearing age does not necessarily mean an increasing proportion of children as in-migrants transferred low-fertility models of the family from the city centre.

Similarly, the highest percentage of the working age population (the total of the mobile and immobile population), was found in Kraków in 1988, 1995 and in 2002. However, in 2012, this index was almost the same in all the zones studied. As a result of the migration balance in Kraków (at least in the official statistics), and the growing migration balance in the suburban area and commuting zones, there was a decrease in the share of the working age population in Kraków in the early years of the twenty-first century. It was also influenced by the tides of demographic highs and lows (the generation of the postwar baby boom was retiring or there was a shrinking supply of the working age group due to an ever smaller group of people born in the second half of the 1990s). The suburban 
[\%]

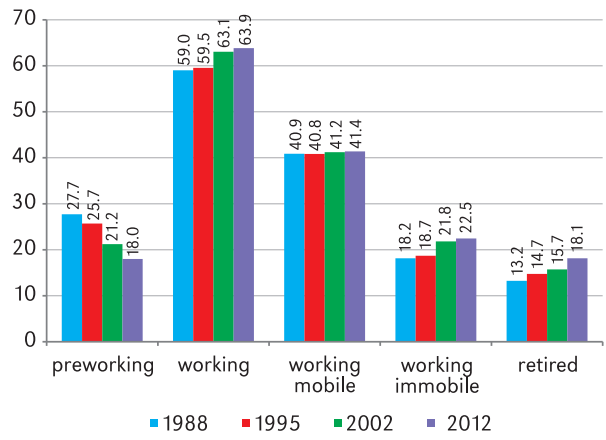

Figure 2. The variation in the age structure of the population in the Kraków Metropolitan Area (KMA) in 1988, 1995, 2002 and 2012 (in percent) Source: our analysis based on data from the Central Statistical Office (the same applies to Figs. 3, $4,5,6,7$ and 8).

[\%] 35

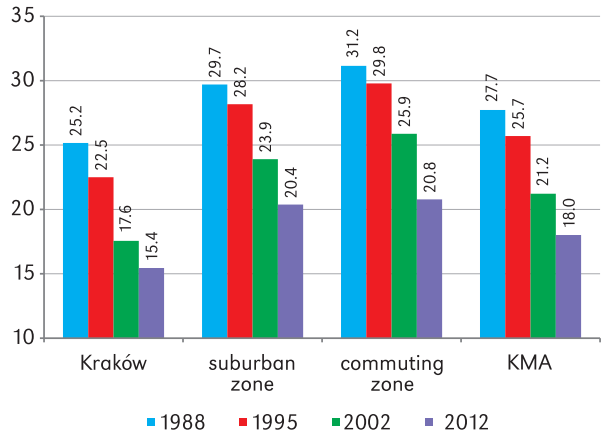

Figure 3. Changes in the percentage of the preworking age population in the zones of the KMA: 1988-2012

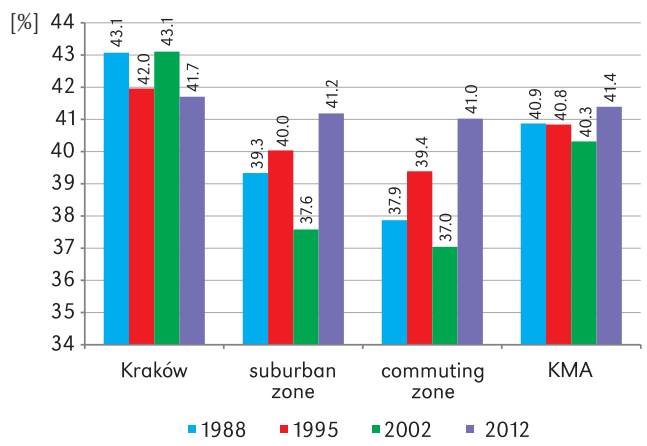

Figure 4. Changes in the percentage of the mobile working age population in the zones of the KMA: 1988-2013 area and commuting zone have recorded growths in the proportions of the working age population since the mid-1990s. In the group of the mobile working age group, there was symmetry in the changes between the city centre and the outer zones of the metropolitan area (Fig. 4). While in the late 1980s and 1990s there was a decline in the percentages of people of younger working age in Kraków, in both the suburban area and commuting zone, there has also been an increase in the share of this population group. On the other hand, at the turn of the century, this situation was reversed and in recent years, Kraków now experiences a decline of the mobile population and there is an increase in the proportion of this group of people in the outer areas.

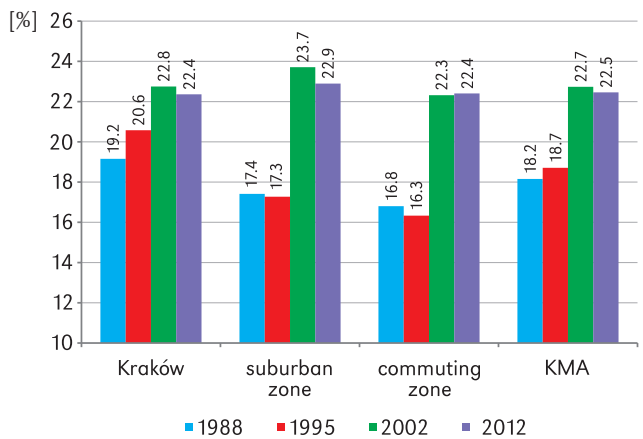

Figure 5. Changes in the percentage of the immobile working age population in the zones of the KMA in the years: 1988-2012

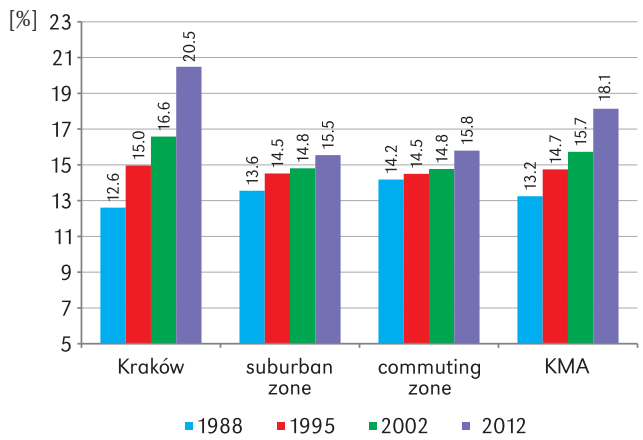

Figure 6. Changes in the percentage of the retirement age population in the zones of the KMA:1988-2012 
The largest increase of the immobile working age population occurred in the suburban area and the commuting zone, especially in the late 1990s (Fig. 5). In the last decade the suburban area recorded a decline of almost 1 per cent in the share of this group of population. The largest change concerned those of retirement age. In 1988 the highest percentage of this group was noted in the commuting zone and the lowest in Kraków itself, but in the last period considered, Kraków had the highest value index (Fig. 6).

When examining changes in the age structure of the population, it is worth referring to dynamic indices, such as an indicator of 'economic ageing' $\left(I_{E A}\right)$ (Kurek 2008), based on percentage differences between the 4 economic age groups in the two time periods,

$$
\begin{aligned}
I_{E A}= & {\left[P_{(0-17) t}-P_{(0-17) t+n}\right]+\left[P_{(18-44) t}-P_{(18-44) t+n}\right]+} \\
& +\left[P_{(45-59 / 64) t+n}-P_{(45-59 / 64) t}\right]+\left[P_{(60 / 65+) t+n}-P_{(60 / 65+) t}\right]
\end{aligned}
$$

where:

$P_{(0-17)} \quad$ - share of population of pre-working age ( $0-17$ years) at the beginning $(t)$ and at the end $(t+n)$ of the study period,

$P_{(18-44)}$ - share of population of young working age (18-44 years) at the beginning ( $\mathrm{t}$ ) and at the end $(t+n)$ of the study period,

$P_{(45-59 / 64)}$ - share of population of older working age (45-59 years for females and 45-64 years for males) at the beginning ( $t$ ) and at the end $(t+n)$ of the study period,

$P_{(60 / 65+)}$ - share of population of post-working age (60 and more years for females and 65 and more years for males) at the beginning ( $(t)$ and at the end $(t+n)$ of the study period.
A positive value of the index of changes in the age structure indicates an ongoing process of ageing of the population in the given unit in the period analysed, and the higher the value of the index, the more dynamic is this process. By analogy, a negative value of the index highlights the fact that the population is rejuvenating.

Observing the changes of this indicator leads us to conclude that this process is tending to slow down in the suburban zone of the KMA and in Kraków itself, although in recent years there was also an increase in the rate of ageing within the commuting zone where the annual values are now the highest (Tab. 3). This condition is due to the decrease in population growth, which was previously very high because of high birth rates.

An analysis of the fertility trends in the study area shows that they do not diverge from national trends. In all rings the birth rates recorded a considerable decrease from 19882003, then a slight increase was observed (until 2009). This increase was associated with an improvement in the economic situation, a boom in the housing market and Poland joining the European Union; however, in recent years, when a financial crisis occurred, another downturn has been noted (Fig. 7). The differences between the inner city and the commuting as well as the suburban zone diminished in the study period. A similar situation was noted with regard to the total fertility rate with the lowest values in Kraków itself and slightly higher values in adjacent regions (Fig. 8). It should be noted, however, that the level of fertility in all the metropolitan area is far below replacement level, not exceeding 1.4.

Table 3. Changes in the dynamics of ageing in different areas of the KMA based on an indicator of economic ageing

\begin{tabular}{|l|c|c|c|}
\hline \multicolumn{1}{|c|}{ Economic Ageing Index } & $1988-1995$ & $1995-2002$ & $2002-2012$ \\
\hline Kraków & 7.5 & 9.1 & 5.5 \\
Suburban Zone & 1.6 & 8.4 & 4.9 \\
Commuting Zone & -0.3 & 6.8 & 8.0 \\
Kraków Metropolitan Area (KMA) & 4.1 & 8.2 & 6.1 \\
KMA without Kraków & 0.2 & 7.3 & 7.1 \\
\hline
\end{tabular}




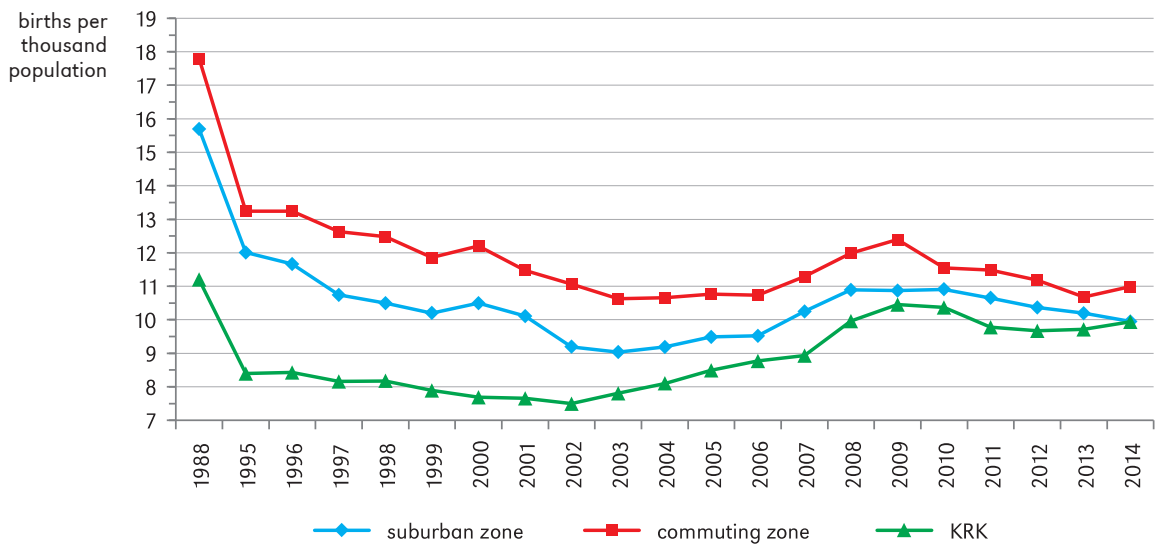

Figure 7. Birth rates in Kraków Metropolitan Area and adjacent zones: 1988-2012

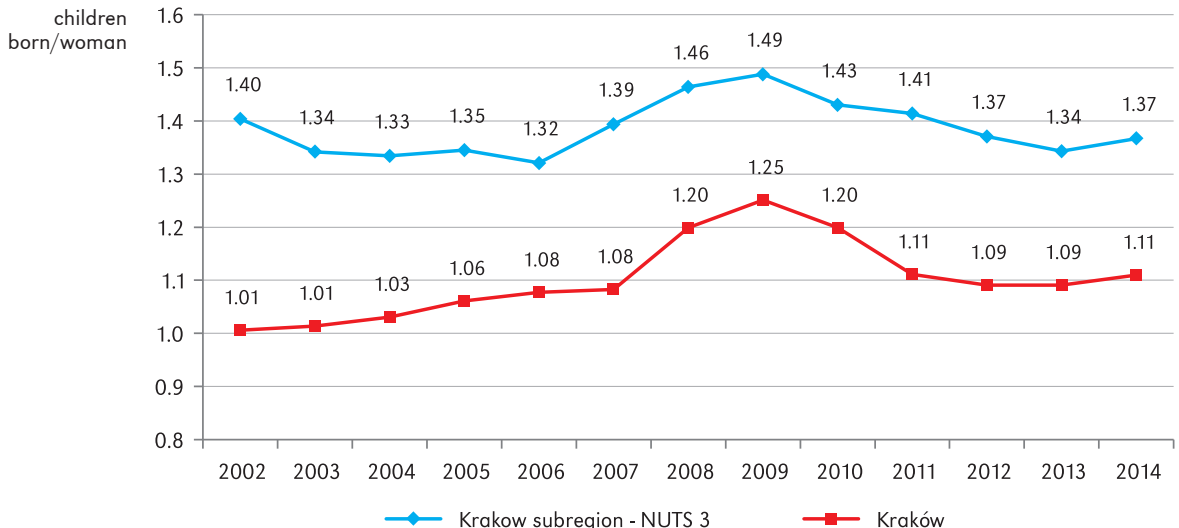

Figure 8. Total Fertility Rates in Kraków and the Kraków subregion - NUTS 3 (Nomenclature of Units for Territorial Statistics, Level Three): 2002-2012

\section{Summary and discussion}

This study revealed that suburbanisation contributes neither to a rejuvenation of the population nor to an increase in the fertility level resulting from changes associated with the second demographic transition. The model of the small family has spread from the inner city to the suburban zones and, therefore, changing the place of living in association with an improvement in living conditions (larger size of houses, and a garden) will not necessarily bring about an increase in fertility. From the above analysis it shows that the effect of suburbanisation on the changes in the age structure is not clearly defined. In the entire KMA, suburbanisation itself has had little effect on changes in the age structure of the population period studied. The proportion of pre-working population declined while the share of elderly increased, notably in the KMA In some municipalities, however, with intense suburbanisation occurring, an inhibition of the aging process has been observed in recent years. Despite the large influx of people from younger age 
groups, there is no increase in the share of children, due to the processes associated with the second demographic transition and the spread of low fertility as well as the urban family model from the core to the suburban zone. Although it is higher than in the city centre, the changes in the level of fertility in suburban areas have been in line with national trends in the demographic and ageing processes. Only in the case of the working population cohort were positive changes recorded from 2002-2012 with an increase of younger workers in the suburban and commuting zone as well as a decrease of older workers in inner city and suburban areas.

An important factor contributing to the slow-down in population ageing relates to the volume and age structure of in-migrants from Kraków; almost 80 percent of these are under 45 years; they reside mostly in the suburban zone. It should also be noted that the intensity of migration to the suburban area was not so high as to significantly influence the age composition of the total population living in both the suburban and commuting zones. The dynamic ageing index showed that while there was a slow-down in the ageing process compared to an earlier period, it affected both the suburban areas and the inner city. The reason for this is that suburbanisation is not only a stage of urban development operating in the Kraków Metropolitan Area. We have also observed the process of a reurbanization of the inner city. Kraków, being a university town, attracts many young people and offers better job opportunities than non-metropolitan areas (Haase et al. 2010; Steinführer et al. 2010). The co-existence of an intensifying suburbanisation and a developing reurbanisation, which is mainly driven by younger households, is widely recognised in the literature (Kabisch \& Haase 2011).

According to van den Berg's traditional model describing urban development (van den Berg et al. 1982), the process of suburbanisation is predominant in Kraków and other cities in CEE, and accompanies a process of reurbanisation and gentrification. Modern development of the Kraków urban region can be seen in the context of the concept of heteropolitanisation, associated with the emergence of new social and spatial patterns in the CEE city, including increased socio-spatial mixing and demographic changes across the urban space (Gentile et al. 2012). A large inflow of new population groups coming from both metropolitan and non-metropolitan areas results in the mixture of age composition within the KMA, but is not changing the direction of rejuvenation. We find that some of the recent research on reurbanisation identifies this rejuvenation process or at least notes a coincidence between ageing processes and rejuvenation trends (Haase et al. 2010). A moderate, inner-city resurgence and a continuation of the process of suburbanisation of the main Polish cities (namely Warsaw and Kraków) was mentioned by Kabisch et al. (2012). They pointed out that both these cities are large university cities with a multifunctional economic structure and a growing service sector. Despite the migration of students and young professionals contributing to a slight population growth in both inner cities and suburban areas, the outward diffusion of the behaviours associated with the second demographic transition also contributes to a weak impact on the deceleration of ageing (Steinführer $\&$ Haase 2007).

Fertility rates are currently well below replacement level and the in-migration of young people does not necessarily contribute to an increase in birth rates. It merits nothing, however, that differences in the level of demographic ageing and the dynamics of ageing processes are subject to a number of complex factors and past demographic events. The impact of past migration to cities is still evident as are declining fertility rates. It is anticipated that in the future there will be a large influx of youth from Kraków itself to other parts of the suburban areas and commuting zones, both of which will somewhat depend on the future real estate market and the region's overall economic conditions.

It seems that despite the young age composition of new suburbanites, fertility behaviour associated with the second demographic 
transition does not have a strong impact on the deceleration of population ageing. This can be analysed along with the concept of heteropolitanisation, which is induced by both global and local influences. The results from a post-socialist city can contribute to international urban theory in that modern demographic changes in suburban areas are more complex and spatially differentiated. The processes described above could also be applied outside the post-socialist context.

\section{References}

Bayona-Carrasco J., Gll-Alonso F., 2012. Suburbanization and international Immigration: the case of the Barcelona Metropolitan Region (1998-2009). Tijdschrift voor Economische en Sociale Geografie, vol. 103, no. 3, pp. 312-329.

Botev N., 2012. Population ageing in Central and Eastern Europe and its demographic and social context. European Journal of Ageing, vol. 9, no. 1, pp. 69-79.

CheshiRe P., 1995. A new phase of urban development in Western Europe? The evidence for the 1980s. Urban Studies, vol. 32, no. 7, pp. 1045-1063.

CHIN N., 2002. Unearthing the roots of urban sprawl: A critical analysis of form, function and methodology. London: University College, London, Centre for Advanced Spatial Analysis.

Drozg V., 2004. Spatial development of Slovenian towns in the last decade. Dela, 21, pp. 121-129.

FORD T., 1999. Understanding population growth in the peri-urban region. International Journal of Population Geography, vol. 5, no. 4, pp. 297-311.

Gentile M., Tammaru T., van Kempen R., 2012. Heteropolitanization: Social and spatial change in Central and East European cities. Cities, vol. 29, no. 5, pp. 291-299.

Haase A., Kabisch S., Steinführer A., BouzarovskI S., Hall R., Ogden P., 2010. Emergent spaces of reurbanization: Exploring the demographic dimension of inner-city residential change in a European setting. Population, Space and Place, vol. 16, no. 5, pp. 443-463.

\section{Acknowledgements}

The study was funded by the National Science Centre based on the project decision number DEC-2012/05/B/HS4/04200 entitled the "Transformation of selected socio-demographic structures in the Kraków Metropolitan Area".

Editors' note:

Unless otherwise stated, the sources of tables and figures are the authors', on the basis of their own research.

Kabisch N., HaAse D., 2011. Diversifying European agglomerations: Evidence of urban population trends for the 21st Century. Population, Space and Place, vol. 17, no. 3, pp. 236-253.

Kabisch N., HaAse D., HaAse A., 2012. Urban population development in Europe,1991-2008: The examples of Poland and the UK. International Journal of Urban and Regional Research, vol. 36, no. 6, pp. 1326-1348.

Kabisch N., HaAse D., HaAse A., 2010. Evolving reurbanisation? Spatio-temporal dynamics as exemplified by the East German city of Leipzig. Urban Studies, vol. 47, no. 5, pp. 967-990.

Kåhrik A., TAmmaru T., 2008. Suburbanization and residential differentiation in the Tallinn metropolitan area. Urban Studies, vol. 45, nos. 5-6, pp. 1055-1078.

Kerbler B., 2015. Population aging in Slovenia: A spatial perspective. Acta Geographica Slovenica, vol. 55, no. 2, DOI: http://dx.doi. org/10.3986/AGS.1885.

KROLL F., KABISCH N., 2012. The relation of diverging urban growth processes and demographic change along an urban-rural gradient. Population, Space and Place, vol. 18, no. 3, pp. 260-276.

KUREK S., 2008. Typologia starzenia się ludności Polski w ujęciu przestrzennym. Kraków: Wydawnictwo Naukowe Akademii Pedagogicznej.

KUREK S., 2011a. Double transitions? Regional patterns of population ageing in Poland. Geografiska Annaler: Series B, Human Geography, vol. 93, no. 2, pp. 163-184.

KUREK S., 2011b. Zmiany w strukturze wieku ludności Polski na tle procesów suburbanizacji [in:] 
Does suburbanisation contribute to the rejuvenation of a metropolitan area? Changes in the age...

J. Słodczyk (ed.), Procesy suburbanizacji w wybranych miastach Polski, Studia Miejskie, 3, pp. 81-98.

Kurek S., Rachwat T., Wójtowicz M., 2014. Industrial and commercial suburbanization in postsocialist city: The Kraków Metropolitan Area (Poland). Annales Universitatis Paedagogicae Cracoviensis Studia Geographica, 5, pp. 55-76.

LeetmaA K., Tammaru T., 2007. Suburbanization in countries in transition: Destinations of suburbanizes in the Tallinn Metropolitan Area. Geografiska Annaler: Series B. Human Geography, vol. 89, no. 2, pp. 127-146.

LIsowski A., Grochowski M., 2008. Procesy suburbanizacji. Uwarunkowania, formy i konsekwencje [in:] Ekspertyzy do Koncepcji Przestrzennego Zagospodarowania Kraju 2008-2033. Warszawa.

LORD S., LUXEMBOURG N., 2006. The mobility of elderly residents living in suburban territories. Journal of Housing for the Elderly, vol. 20, no. 4, pp. 103-121.

MARCińCZAK S., 2012. The evolution of spatial patterns of residential segregation in Central European Cities: The Łódź Functional Urban Region from mature socialism to mature post-socialism. Cities, vol. 29, no. 5, pp. 300-309.

Minal B., Nistor C., Simion G., 2015. Post-socialist urban growth of Bucharest, Romania - A change detection analysis on Landsat imagery (19842010). Acta Geographica Slovenica, vol. 55, no. 2, DOI: http://dx.doi.org/10.3986/AGS.709

OuŘEDniČEk M., 2003. Suburbanizace Prahy. Czech Sociological Review, vol. 39, no. 2, pp. 235-253.

OUŘEDNIČEK M., 2007. Differential suburban development in the Prague Urban Region. Geografiska Annaler: Series B. Human Geography, vol. 89, no. 2, pp. 11-126.

OuŘEDníČEK M., Temelová J., 2009. Twenty years after socialism: The transformation of Prague's inner structure. Studia Universitatis Babeș-Bolyai - Sociologia, vol. 54, no. 1, pp. 9-30.

Pavlova M.K., Silbereisen R.K., 2012. Perceived level and appraisal of the growing expectations for active ageing among the young-old in Germany. Research on Aging, vol. 34, no. 1, pp. 80-99.

PHILLIPS M., 2010. Counterurbanisation and rural gentrification: An exploration of the terms. Population, Space and Place, vol. 16, no. 6, pp. 539-558.
Pichler-Milanović N., 2014. European urban sprawl: Sustainability, cultures of (anti)urbanism and "hybrid cityscapes". Dela, 27, pp. 101-133.

PZPWM, 2003. Plan Zagospodarowania Przestrzennego Województwa Małopolskiego. Kraków: Urząd Marszałkowski Województwa Małopolskiego.

REBERNIK D., 2004. Recent development of Slovene towns - Social structure and transformation. Dela, 21, pp. 139-144.

Rees P. , van der Gaag N., de Beer J., Heins F., 2012. European regional populations: Current trends, future pathways, and policy options. European Journal of Population, vol. 28, no. 4, pp. 385-416.

Rogers A., Raymer J., 1999. The regional demographics of the elderly foreign-born and nativeborn populations in the United States since 1950. Research on Aging, vol. 21, no. 1, pp. 3-35.

RosenbloOm S., 2003. The mobility needs of older Americans: Implications for transportation reauthorization. Transportation Reform Series, Washington, DC: Brookings Institution, https://www.brookings.edu/wp-content/uploads/2016/06/20030807_Rosenbloom.pdf [3 January 2016].

Sedlakova A., 2005. The city-periphery migration and the process of suburbanization in Czech and Slovak post-communist cities [in:] T. Michalski (ed.), Geographical Aspects of Transformation Process in Central and East-Central Europe, Pelplin: Wydawnictwo-Bernardinum, pp. 71-78..

Sharma A., 2012. The chain is only as strong as the weakest link: Older adult migration and the first move. Research on Aging, vol. 35, no. 5, pp. 507-532.

SHUCKSMITH M., 2011. Exclusive rurality: Planners as agents of gentrification. Interface, Planning, Theory and Practice, vol. 12, no. 4, pp. 605-611.

Song L., LI S., Feldman M.W., 2012. Out-migration of young adults and gender division of intergenerational support in rural China. Research on Aging, vol. 34, no. 4, pp. 399-424.

Steinführer A., Bierzyński A., Grossman K., HaAse A., Kabisch S., Klusácek P., 2010. Population decline in Polish and Czech cities during post-socialism? Looking behind the official statistics. Urban Studies, vol. 47, no. 11, pp. 2325-2346

Steinführer A., HaAse A., 2007. Demographic change as a future challenge for cities in East 
Central Europe. Geografiska Annaler: Series B. Human Geography, vol. 89, no. 2, pp. 183-195.

StockDAle A., 2011. A review of demographic ageing in the UK: Opportunities for rural research. Population, Space and Place, vol. 17, no. 3, pp. 204-221.

Stockdale A., Catney G., 2014. A life course perspective on urban-rural migration: The importance of the local context. Population, Space and Place, vol. 20, no. 1, pp. 83-98.

SWiaczny F., Graze P., Schlömer C., 2008. Spatial impacts of demographic change in Germany: Urban Population Processes Reconsidered. Zeitschrift für Bevölkerungswissenschaft, vol. 33, no. 2, pp. 181-205.

SÝKORA L., BOUZAROVSKI S., 2012. Multiple transformations: Conceptualising the post-communist urban transition. Urban Studies, vol. 49, no. 1, pp. 43-60.

SÝKORA L., OUŘEeDníčEK M., 2007. Sprawling postcommunist metropolis: Commercial and residential suburbanisation in Prague and Brno, the Czech Republic [in:] E. Razin, M. Dijst, C. Vázquez (eds.), Employment Deconcentration in European Metropolitan Areas: Market Forces versus Planning Regulations. Dordrecht: Springer, pp. 209-233.
Van den Berg L., Drewett R., KlaAsen L.H., Rossi A., ViJverberg C.H.T., 1982. Urban Europe: A study of growth and decline. Oxford: Pergamon Press.

Walford N.S., KuREK S., 2008. A comparative analysis of population ageing in urban and rural areas of England and Wales, and Poland over the last three census intervals. Population, Space and Place, vol. 14, no. 5, pp. 365-386.

ZBOROWSKI A., 2005. Przemiany struktury społeczno-przestrzennej regionu miejskiego w okresie realnego socjalizmu i transformacji ustrojowej (na przykładzie Krakówa). Kraków: Instytut Geografii i Gospodarki Przestrzennej Uniwersytetu Jagiellońskiego.

Zborowski A., Chaberko T., Grad N., Kretowicz P., 2010. Delimitacja Krakowskiego Obszaru Metropolitalnego [in:] Badanie funkcji, potencjału oraz trendów rozwojowych miast w województwie małopolskim, Elaborat, Kraków: Urząd Marszałkowski Województwa Małopolskiego.

Zeitler E., Buys L., Aird R., Miller E., 2012. Mobility and active ageing in suburban environments: Findings from in-depth interviews and personbased GPS tracking. Current Gerontology and Geriatrics Research, vol. 2012, no. 3, pp. 1-10. 